\title{
P-Glycoprotein in the Blood-Brain Barrier of Mice Influences the Brain Penetration and Pharmacological Activity of Many Drugs
}

\author{
Alfred H. Schinkel, Els Wagenaar, Carla A.A.M. Mol, and Liesbeth van Deemter \\ The Netherlands Cancer Institute, Division of Molecular Biology, 1066 CX Amsterdam, The Netherlands
}

\begin{abstract}
The mouse mdr1a (also called mdr3) P-GP is abundant in the blood-brain barrier, and its absence in mdr1a $(-/-)$ mice leads to highly increased levels of the drugs ivermectin, vinblastine, digoxin, and cyclosporin $\mathrm{A}$ in the brain. We show here that the drugs loperamide, domperidone, and ondansetron are transported substrates for the mouse mdr1a P-GP and its human homologue MDR1. Phenytoin is a relatively weaker substrate for each, and the drugs haloperidol, clozapine, and flunitrazepam are transported hardly or not at all. Tissue distribution studies demonstrated that the relative brain penetration of radiolabeled ondansetron and loperamide (and their metabolites) is increased four- and sevenfold, respectively, in mdrla (-I-) mice. A pilot toxicity study with oral loperamide showed that this peripherally acting antidiarrheal agent gains potent opiatelike activity in the central nervous system of mdrla (-I-) mice. mdrla (-I-) mice also showed increased sensitivity to neurolepticlike side effects of oral domperidone. These results point to the possible role that the drug-transporting P-GP(s) may play in the clinical use of many drugs, especially those with potential targets in the central nervous system. (J. Clin. Invest. 1996. 97:2517-2524.) Key words: Multidrug resistance • opiates $\bullet$ reversal agents $\bullet$ neurotoxicity $\bullet$ central nervous system
\end{abstract}

\section{Introduction}

The drug-transporting P-GPs were discovered by their ability to confer multidrug resistance $(\mathrm{MDR})^{1}$ to mammalian tumor cells. These large plasma membrane proteins confer drug resistance by actively extruding a range of cytotoxic drugs from the cell. Transported drugs vary widely in their structure, and the mechanism by which P-GPs can recognize such diverse substrates and translocate them across membranes is not fully understood. The only common structural feature of substrate compounds identified so far is their relatively hydrophobic,

Address correspondence to Alfred H. Schinkel, Division of Molecular Biology, The Netherlands Cancer Institute, Plesmanlaan 121, 1066 CX Amsterdam, The Netherlands. Phone: 31-20-5122087; FAX: 3120-6691383.

Received for publication 27 November 1995 and accepted in revised form 20 February 1996.

1. Abbreviations used in this paper: MDR, multidrug resistance; P-GP, P-glycoprotein.

J. Clin. Invest.

(C) The American Society for Clinical Investigation, Inc.

0021-9738/96/06/2517/08 \$2.00

Volume 97, Number 11, June 1996, 2517-2524 amphipathic nature (1-5). These transported compounds include many clinically important drugs, such as anticancer agents (e.g., Vinca alkaloids, anthracyclines, epipodophyllotoxins, taxanes), immunosuppressive drugs (cyclosporin A, FK506), cardiac drugs (e.g., digoxin), anthelmintic agents (ivermectin), and steroids (aldosterone, hydrocortisone, dexamethasone).

Whereas humans have only one drug-transporting P-GP (MDR1), mice have two, mdr1a (also called mdr3) and mdr1b (also called mdr1) $(2,6,7)$. The tissue distribution of these proteins suggests that the two mouse isoforms together perform the same function(s) as the single human MDR1 protein (8-12). We have recently generated mice with a genetic disruption of the mdrla gene (mdrla (-/-) mice) to learn more about the physiological and pharmacological role of the mdr1a P-GP (13). This P-GP is predominantly found in the apical (luminal) membrane of intestinal epithelial cells, in bile canalicular membranes of liver parenchyme cells, and in the endothelial cells of blood capillaries in the brain, at the position of the blood-brain barrier. This localization suggests an overall protective or excretory detoxifying function of the mdr1a P-GP, as originally proposed for the human MDR1 P-GP $(8,12)$. We have demonstrated that the absence of the mdr1a P-GP in mdrla (-/-) mice has a pervasive influence on the tissue distribution and pharmacokinetics of drugs such as ivermectin, vinblastine, cyclosporin A, and digoxin $(13,14)$. In each case, the most striking effects were observed in the brain, owing to the high level of mdr1a P-GP in the blood-brain barrier, combined with the continuous diffusional barrier formed by the tightly joined endothelial cells in the brain.

Recently, quite effective inhibitors of P-GP such as PSC 833 have been described (15), and these so-called reversal agents are currently administered to patients in clinical trials to reverse the chemotherapy resistance of P-GP-expressing tumors (see references 16,17). Our findings in mdrla (-/-) mice suggest that this approach may affect the functional integrity of the blood-brain barrier for P-GP substrate drugs. The resulting increased penetration of certain drugs into the brain may have adverse consequences for their use, as central nervous system (CNS) side effects may increase. However, it is also imaginable that increased brain penetration of some drugs would be highly favorable for therapy, especially when the intended pharmacological target is positioned behind the bloodbrain barrier. In view of these potentially important therapeutic implications of the use of reversal agents, we have tested a series of drugs for their ability to be transported by P-GP. For a selected set of drugs, we have further tested whether the tissue distribution was altered in mdrla $(-/-)$ mice, and whether they had qualitatively altered pharmacological effects in these mice.

The drugs tested include: domperidone and haloperidol, both dopamine antagonists, but with entirely different clinical applications, as domperidone does not enter the CNS, and ha- 
loperidol does; clozapine, a phenothiazine drug used at very high doses to treat therapy-resistant schizophrenia, with rare but life-threatening peripheral side effects such as agranulocytosis or pancytopenia; flunitrazepam as a model benzodiazepine drug; phenytoin, an important antiepileptic drug to which patients sometimes display therapy resistance; ondansetron, an effective antiemetic drug often used during chemotherapy of cancer patients; and loperamide, a commonly used antidiarrheal agent (for drug properties, see reference 18).

Furthermore, we have used the information gained from this analysis of potential P-GP substrate drugs to improve our understanding of the reasons why some compounds are effectively transported by P-GP and others are not.

\section{Methods}

Materials. Domperidone, $\left[{ }^{3} \mathrm{H}\right]$ domperidone $(221 \mathrm{GBq} / \mathrm{mmol})$, haloperidol, $\left[{ }^{3} \mathrm{H}\right]$ haloperidol $(630 \mathrm{GBq} / \mathrm{mmol})$, and $\left[{ }^{3} \mathrm{H}\right]$ loperamide (596 GBq $/ \mathrm{mmol}$ ) were a kind gift of Janssen Pharmaceutica (Beerse, Belgium). Ondansetron and $\left[{ }^{14} \mathrm{C}\right]$ ondansetron $(1,616 \mathrm{MBq} / \mathrm{mmol})$ were a kind gift of Glaxo (Greenford, UK). PSC 833 was a kind gift of Sandoz (East Hanover, NJ). $\left[4-{ }^{14} \mathrm{C}\right] 5,5$-diphenylhydantoin $\left(\left[{ }^{14} \mathrm{C}\right]\right.$ phenytoin) $(2.0 \mathrm{GBq} / \mathrm{mmol}),\left[N\right.$-methyl $\left.-{ }^{3} \mathrm{H}\right]$ clozapine $(3,096.9 \mathrm{GBq} / \mathrm{mmol})$ and [methyl $\left.{ }^{3} \mathrm{H}\right]$ flunitrazepam $(3,174.6 \mathrm{GBq} / \mathrm{mmol})$ were obtained from DuPont-NEN (Wilmington, DE). Inulin $\left[{ }^{14} \mathrm{C}\right]$ carboxylic acid (220 MBq/mmol) was from Amersham Int. (Little Chalfont, UK). Clozapine and flunitrazepam were obtained from BUFA (Uitgeest, The Netherlands). Other chemicals and drugs were obtained from Sigma Chemical Co. (St. Louis, MO).

Cell lines, tissue culture, and transport assays. The pig-kidney epithelial cell line LLC-PK1 was obtained from the American Type Culture Collection (Rockville, MD) and cultured as described (14). The generation of the MDR1- and mdrla-transfected LLC-PK1 subclones L-MDR1 and L-mdr1a was described previously (14). Transport assays were carried out as described $(19,20,14)$. Complete medium including L-glutamine, penicillin, streptomycin, and FCS was used throughout. Cells were seeded on microporous polycarbonate membrane filters $\left(3.0-\mu \mathrm{m}\right.$ pore size, $24.5-\mathrm{mm}$ diameter, Transwell ${ }^{\mathrm{TM}}$ 3414 , Costar Corp., Cambridge, MD) at a density of $2 \times 10^{6}$ cells per well for LLC-PK1, L-MDR1, and L-mdr1a. The cells were grown for $3 \mathrm{~d}$ in complete medium with one medium replacement. $1-2 \mathrm{~h}$ before the start of the experiment, medium at both the apical and the basal side of the monolayer was replaced with $2 \mathrm{ml}$ of complete medium. The experiment was started $(\mathrm{t}=0)$ by replacing the medium at either the apical or the basal side of the cell layer with $2 \mathrm{ml}$ of complete medium containing the appropriate concentration of the radiolabeled drug (at 3.7-9.3 kBq/ml), and ${ }^{14} \mathrm{C}$-labeled inulin $(0.93 \mathrm{kBq} / \mathrm{ml}, 4.2 \mu \mathrm{M}$. Not added when ${ }^{14} \mathrm{C}$-labeled drugs were tested). The cells were incubated at $37^{\circ} \mathrm{C}$ in $5 \% \mathrm{CO}_{2}$, and $50-\mu \mathrm{l}$ aliquots were taken from each compartment at 1,2,3, and $4 \mathrm{~h}$. The appearance of radioactivity in the opposite compartment was measured and presented as the fraction of total radioactivity added at the beginning of the experiment. Directional transport was measured in duplicate and presented with a range bar. The paracellular flux was monitored by the appearance of inulin $\left[{ }^{14} \mathrm{C}\right]$ carboxylic acid in the opposite compartment and was always $<1.5 \%$ of total radioactivity per hour.

Drug distribution studies. Drug distribution experiments were carried out as described $(13,14)$. Male mice between 9 and $14 \mathrm{wk}$ of age were analyzed using three mice in each (genetically matched) group. Mice of FVB or mixed (FVB and 129/Ola) genetic background were used. Drugs for intravenous injection were formulated such that $5 \mu \mathrm{l}$ drug solution per g body weight was injected into the tail vein of mice lightly anesthetized with diethyl ether (injection time: $5 \mathrm{~s}$ ). For oral administration, $10 \mu \mathrm{l}$ drug solution per g of body wt was dosed by gavage into the stomach. Formulations for injection were as follows: Domperidone $(0.2 \mathrm{mg} / \mathrm{ml})$ was dissolved in $20 \%$ (vol/vol) 1,2-pro- panediol, 4\% (wt/vol) D-glucose; haloperidol (0.2 or $0.04 \mathrm{mg} / \mathrm{ml}$ ) was dissolved in $5 \%$ (wt/vol) D-glucose, brought to $\mathrm{pH} 5$ with $\mathrm{HCl}$; clozapine $(0.2 \mathrm{mg} / \mathrm{ml})$ was dissolved in $6 \%$ ( vol $/ \mathrm{vol})$ polyethylene glycol 400, 3\% (vol/vol) ethanol, $1 \%$ (vol $/ \mathrm{vol})$ Tween-80, and $4.5 \%(\mathrm{wt} / \mathrm{vol})$ D-glucose; phenytoin $(0.04 \mathrm{mg} / \mathrm{ml})$ was dissolved in $0.9 \%(\mathrm{wt} / \mathrm{vol}) \mathrm{NaCl}$ brought to $\mathrm{pH} 8.5$ with $\mathrm{NaOH}$; ondansetron $(0.04 \mathrm{mg} / \mathrm{ml})$ was dissolved in $5 \%(\mathrm{wt} / \mathrm{vol})$ D-glucose; and loperamide $(0.1 \mathrm{mg} / \mathrm{ml})$ was dissolved in $5 \%(\mathrm{vol} / \mathrm{vol}) 1,2$-propanediol and $4.75 \%(\mathrm{wt} / \mathrm{vol}) \mathrm{D}$-glucose. Labeled drugs were added after appropriate dilution of drug stocks. Between 18.5 and $37 \mathrm{kBq}$ was injected per mouse. At specific time points, mice were anesthetized and completely bled by orbital traction, thus removing most of the blood content of tissues. Heparin plasma was obtained from the collected blood by centrifugation. Tissues were collected, weighed, and homogenized in $4 \%$ (wt/vol) BSA. Blood-rich organs such as liver were dabbed on filter paper to remove most of the remaining blood. The contents of stomach, small intestine, and colon were removed before homogenizing the tissues, whereas the gall bladder was processed with its bile content included. 200- $\mu$ l aliquots of plasma or homogenized tissue were transferred to counting fluid (Ultima Gold; Packard Instruments, Meriden, CT) and radioactivity was determined by liquid scintillation counting. The statistical significance of differences found between radioactivity levels in tissues of wild-type and $m d r 1 a(-/-)$ mice was assessed using Student's unpaired two-tailed t test.

Pilot toxicity studies. For oral pilot toxicity studies, $10 \mu \mathrm{l}$ drug solution per gram body wt was administered by gavage into the stomach of mice starved for $20 \mathrm{~h}$. Doses of 5,10,20,40, or $80 \mathrm{mg} / \mathrm{kg}$ of domperidone dissolved in 1,2-propanediol were administered to female mdr1a (-/-) or wild-type mice of the FVB strain (two mice in each group at 5 and $10 \mathrm{mg} / \mathrm{kg}$, and four mice in each group at 20, 40, and 80 $\mathrm{mg} / \mathrm{kg}$ ). For loperamide, doses of $5,10,20,40,80$, or $160 \mathrm{mg} / \mathrm{kg}$ dissolved in 1,2-propanediol were administered to male mdr1a $(-/-)$ or wild-type mice of mixed (FVB and 129/Ola) genetic background (three mice in each group).

\section{Results}

To test whether certain drugs are good P-GP substrates, we made use of the polarized pig-kidney epithelial cell line LLCPK1 transfected with either a human MDR1, or a mouse $m d r 1 a$ cDNA (14). These three cell lines (LLC-PK1, L-MDR1, and L-mdr1a, respectively) were grown to confluent polarized monolayers on porous membrane filters, and polarized transepithelial transport of radiolabeled compounds was subsequently determined as described $(19,20,14)$. L-MDR1 and L-mdr1a cells have roughly comparable levels of P-GP (14).

Fig. 1 shows the results obtained with the two dopamine antagonist drugs $\left[{ }^{3} \mathrm{H}\right]$ domperidone (top row) and $\left[{ }^{3} \mathrm{H}\right]$ haloperidol (second row). Domperidone is a very good substrate for both the MDR1 and the mdr1a P-GP, demonstrating increased transport in the apical direction, and markedly decreased transport in the basal direction. In fact, significant polarized transport was observed in the parental LLC-PK1 cells. This is most likely mediated by the trace level of endogenous porcine P-GP present in these cells $(20,14)$. In contrast, $\left[{ }^{3} \mathrm{H}\right]$ haloperidol was not detectably transported in the parental or L-MDR1 cells, whereas only a low, albeit significant, level of transport was observed in L-mdr1a cells. This shows that haloperidol is at best a poor substrate for the mdr1a P-GP, and even less so for the human MDR1 P-GP. The two drugs, $\left[{ }^{3} \mathrm{H}\right]$ flunitrazepam and $\left[{ }^{3} \mathrm{H}\right]$ clozapine, a hypnotic and an antipsychotic drug, respectively, and thus each active in the CNS, were not detectably transported by the L-MDR1 cell line, and at best very poorly by the L-mdr1a cell line (Fig. 1, third and fourth row, respectively). 

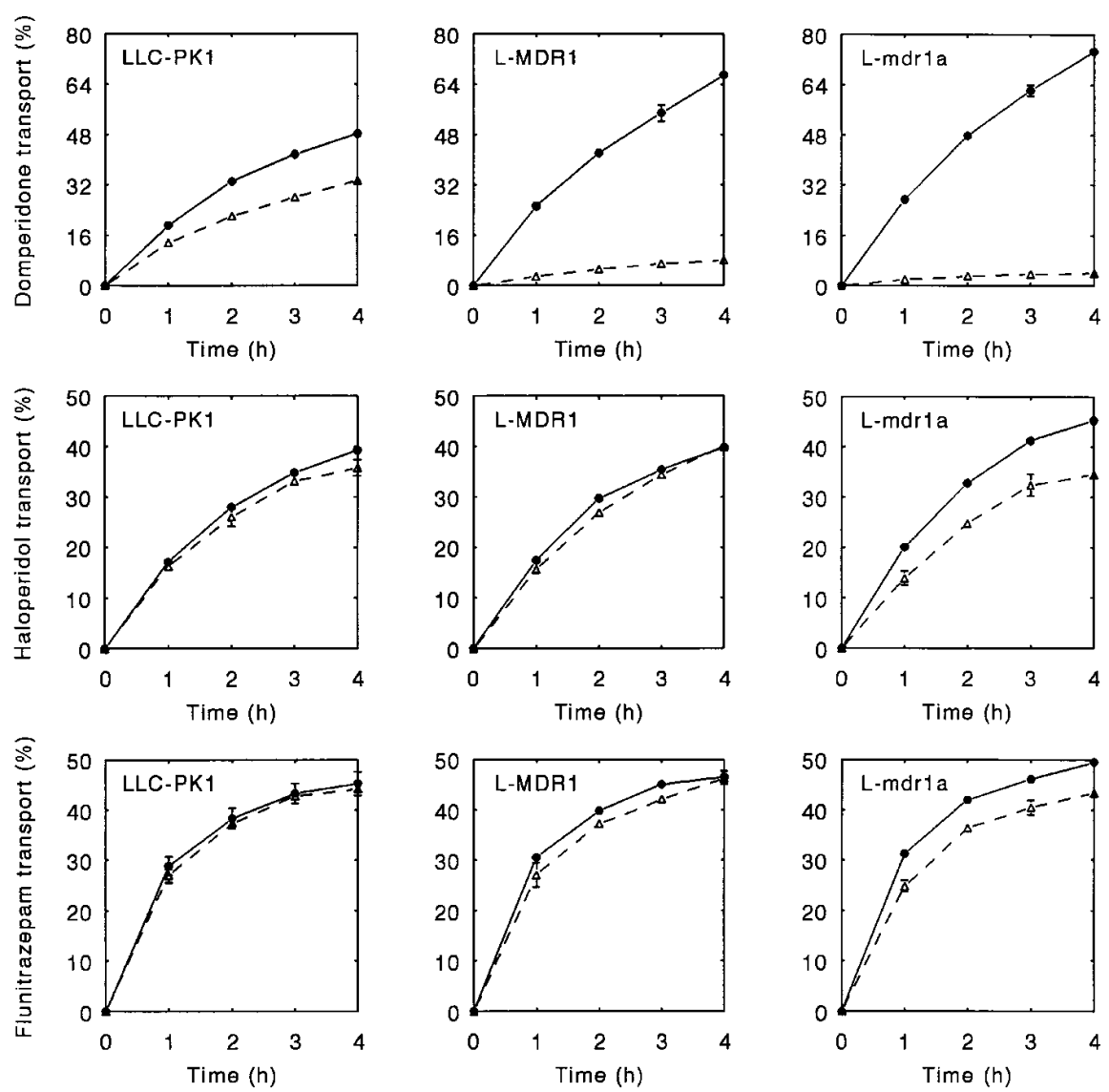

Figure 1. Transepithelial transport of $\left[{ }^{3} \mathrm{H}\right]$ domperidone $(2 \mu \mathrm{M}),\left[{ }^{3} \mathrm{H}\right]$ haloperidol $(50 \mathrm{nM}),\left[{ }^{3} \mathrm{H}\right]$ flunitrazepam $(500 \mathrm{nM})$, and $\left[{ }^{3} \mathrm{H}\right]$ clozapine $(50 \mathrm{nM})$ by LLC-PK1,

L-MDR1, and L-mdr1a monolayers. At $\mathrm{t}=$ 0 , the radioactive drug was applied in one compartment (basal or apical), and the percentage of radioactivity appearing in the op-
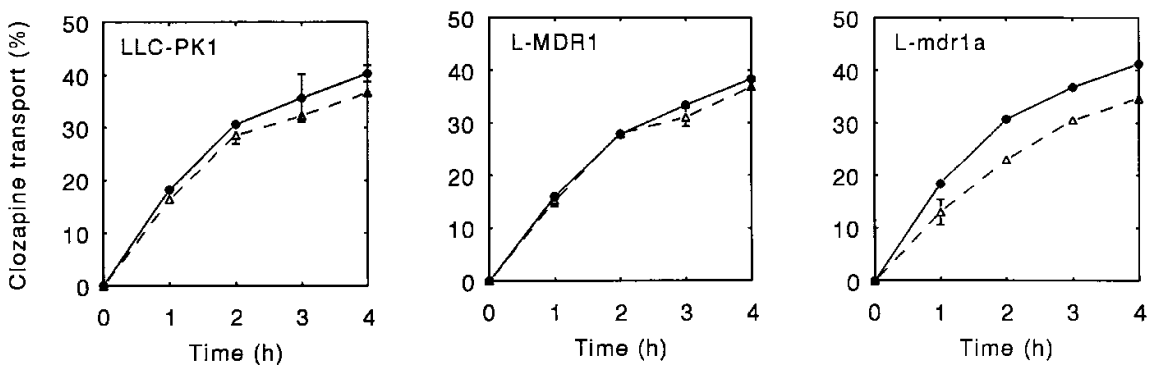
posite compartment at $\mathrm{t}=1,2,3$, and $4 \mathrm{~h}$ was measured and plotted. Experiments were done in duplicate. Bars indicate the range of measured values unless variation was too small to depict clearly. $\triangle$, dashed line, translocation from apical to basal compartment; $\bullet$, solid line, translocation from basal to apical compartment. Note that for different drugs, different percentage scales were used to plot transport.

The antiepileptic drug $\left[{ }^{14} \mathrm{C}\right]$ phenytoin was slightly transported by the L-MDR1 cell line, but more substantially by the L-mdr1a cells (Fig. 2, top row). This transport could be effectively inhibited by $5 \mu \mathrm{M}$ of PSC 833 (data not shown). It is interesting to note that phenytoin is a weak acid ( $\mathrm{p} K_{\mathrm{a}} \sim 8.3$ ), so this experiment shows that not only weakly basic or uncharged compounds can be substrates of the drug-transporting P-GPs, but also weakly acidic drugs. Tishler et al. (21) already suggested that P-GP could transport phenytoin based on decreased accumulation of phenytoin in a P-GP-containing cell line. The antiemetic drug $\left[{ }^{14} \mathrm{C}\right]$ ondansetron was clearly transported by the human MDR1 P-GP, and still more efficiently by the mouse mdr1a P-GP, and this transport was effectively inhibited by the addition of 5 $\mu \mathrm{M}$ PSC 833 (Fig. 2, second and third rows). The results depicted in Fig. 2, second row, directly demonstrate that P-GP can accumulate a substrate against a macroscopic concentration gradient, as at the end of the experiment fourfold more $(80 \%)$ ondansetron was present on the apical side of the L-mdr1a cell layer than on the basal side (20\%), where all the drug was originally added. A similar result was seen with domperidone transport by the mdr1a P-GP (Fig. 1). Finally, the antidiarrheal opioid drug $\left[{ }^{3} \mathrm{H}\right]$ loperamide was very effectively transported by both the MDR1 and the mdr1a P-GP (Fig. 2, bottom row).

We next wanted to assess the effect of the absence of the mdr1a P-GP in mdrla (-/-) mice on the in vivo distribution of radiolabeled domperidone, phenytoin, ondansetron, and loperamide. As previously demonstrated for ivermectin, vinblastine, digoxin, and cyclosporin $\mathrm{A}$, the most sensitive parameter for such an effect is the degree of distribution of these compounds to the brain of mdr1a (-/-) mice as compared to the brain of wild-type mice $(13,14)$. However, analyses of the total radioactivity can be complicated by rapid metabolism of the drug. When the majority of the generated radiolabeled metabolites are not P-GP substrates, and if they easily penetrate the brain, their presence may completely mask the differences caused by P-GP absence for the parent drug. This might have been the case for $\left[{ }^{3} \mathrm{H}\right]$ domperidone and possibly also for $\left[{ }^{14} \mathrm{C}\right]$ phenytoin, as we were unable to demonstrate clear differences in tissue levels of radioactivity between mdrla $(-/-)$ and wild-type mice $4 \mathrm{~h}$ after intravenous administration of 

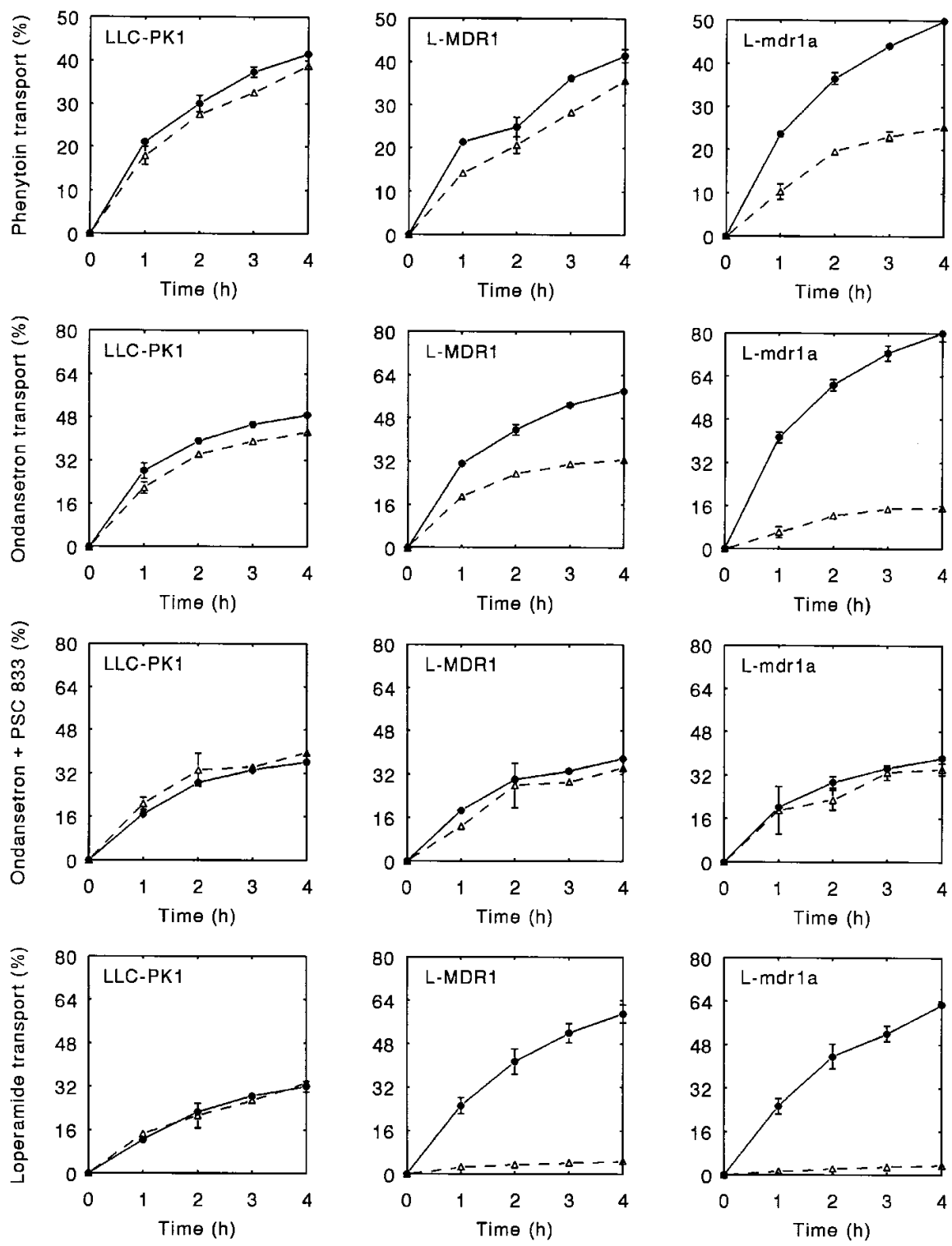

Figure 2. Transepithelial transport of $\left[{ }^{14} \mathrm{C}\right]$ phenytoin $(2 \mu \mathrm{M}),\left[{ }^{14} \mathrm{C}\right]$ ondansetron $(2$ $\mu \mathrm{M}),\left[{ }^{14} \mathrm{C}\right]$ ondansetron $(2 \mu \mathrm{M})$ in the presence of PSC $833(5 \mu \mathrm{M})$, and $\left[{ }^{3} \mathrm{H}\right] \mathrm{lo}-$ peramide $(2 \mu \mathrm{M})$ by LLC-PK1, L-MDR1, and L-mdr1a cells. Experiments were carried out as described in the legend of Fig. 1. $\triangle$, dashed line, translocation from apical to basal compartment;, solid line, translocation from basal to apical compartment. Note that for different drugs, different percentage scales were used to plot transport.

$\left[{ }^{3} \mathrm{H}\right]$ domperidone or $\left[{ }^{14} \mathrm{C}\right]$ phenytoin (not shown). Even after a relatively short distribution period chosen to minimize the degree of metabolism, no substantial difference could be found (30 min, data not shown). As domperidone is a very good P-GP substrate in vitro, we think that this lack of apparent difference may be explained by the rapid metabolism of $\left[{ }^{3} \mathrm{H}\right]$ domperidone in the mouse. For instance, in male rats domperidone is rapidly metabolized, with plasma levels of labeled metabolites surpassing the level of unchanged drug 3 min after injection (22).

Clear support for a role of mdr1a P-GP in the pharmacological handling of domperidone came from an oral toxicity test of domperidone in mdrla $(-/-)$ and $(+/+)$ mice. When dosages of $5,10,20,40$, or $80 \mathrm{mg} / \mathrm{kg}$ of domperidone were administered, the $m d r l a(-/-)$ mice at 20,40 , and $80 \mathrm{mg} / \mathrm{kg}$ demonstrated a transient period of extreme passivity, crouched posture, and total lack of spontaneous movement or exploratory behavior, even when handled. This lasted from about $30 \mathrm{~min}$ to $2 \mathrm{~h}$ after administration, after which most mice gradually recovered (one mouse at $80 \mathrm{mg} / \mathrm{kg}$ maintained a crouched posture and died after $1.5 \mathrm{~d}$ ). Effects were more intense and lasted longer at the higher dosages. In contrast, wild-type mice given the same dosages did show some passivity during this period, but they remained fully explorative upon disturbance, suggesting lower levels of domperidone in the CNS of wild-type mice. As the mdr1a P-GP is abundant in the intestinal epithelium, an increased oral bioavailability of domperidone in $\operatorname{mdrla}(-/-)$ mice may also have contributed to the observed differences.

With $\left[{ }^{14} \mathrm{C}\right]$ phenytoin, as with domperidone, potential differences in tissue distribution may also have been masked by metabolism, but phenytoin is clearly a less efficient substrate for the mdr1a P-GP, so it could also be that the effect of the absence of mdr1a P-glycoprotein is small for this drug. We did not find differences in tissue distribution of radioactivity $4 \mathrm{~h}$ after intravenous administration of $\left[{ }^{3} \mathrm{H}\right]$ haloperidol or $\left[{ }^{3} \mathrm{H}\right]$ clozapine to mdrla (-/-) and wild-type mice (data not shown). This was expected from the fact that these compounds are at best poor substrates for the mdr1a P-GP.

Intravenous administration of $\left[{ }^{14} \mathrm{C}\right]$ ondansetron at $0.2 \mathrm{mg} /$ $\mathrm{kg}$ resulted in a clearly (fourfold) higher level of radioactivity in the brain 30 min after injection, whereas the plasma level 
Table I. Tissue Levels of Radioactivity in mdrla $(+/+)$ and $(-/-)$ Mice 30 Min after Intravenous Injection of

$\left[{ }^{14} \mathrm{C}\right]$ Ondansetron $(0.2 \mathrm{mg} / \mathrm{kg})$

\begin{tabular}{lccc}
\hline & & & Ratio \\
\cline { 4 - 4 } \multicolumn{1}{c}{ Tissue } & mdr1a $(+/+)$ & $m d r 1 a(-/-)$ & $(-/-):(+/+)$ \\
\hline Brain & $18.7 \pm 3.2$ & $75.6 \pm 2.3$ & $4.0^{*}$ \\
Muscle & $44.7 \pm 8.0$ & $38.0 \pm 5.6$ & 0.9 \\
Heart & $66.7 \pm 5.5$ & $65.0 \pm 5.3$ & 1.0 \\
Kidney & $847 \pm 128$ & $728 \pm 54$ & 0.9 \\
Liver & $582 \pm 72$ & $530 \pm 15$ & 0.9 \\
Gall bladder & $8,454 \pm 6,743$ & $6,537 \pm 2,157$ & 0.8 \\
Lung & $388 \pm 74$ & $418 \pm 67$ & 1.1 \\
Stomach & $252 \pm 86$ & $200 \pm 61$ & 0.8 \\
Small intestine & $324 \pm 58$ & $246 \pm 39$ & 0.8 \\
Colon & $163 \pm 21$ & $165 \pm 37$ & 1.0 \\
Testis & $37.2 \pm 4.2$ & $70.9 \pm 9.7$ & $1.9^{\ddagger}$ \\
Spleen & $142 \pm 24$ & $141 \pm 15$ & 1.0 \\
Plasma & $40.5 \pm 5.4$ & $39.4 \pm 4.0$ & 1.0 \\
& & & \\
\hline
\end{tabular}

Results are expressed as means $\pm \mathrm{SD}(n-1)$ in nanograms per gram tissue $\left(\left[{ }^{14} \mathrm{C}\right]\right.$ ondansetron equivalent). Three mice were analyzed in each group. $* P<0.001 ;{ }^{*} P<0.01$.

and the levels in most other tissues were comparable between wild-type and mdrla (-/-) mice (Table I). Testis also demonstrated a clear (about twofold) difference, in accordance with the presence of an endothelial blood-tissue barrier containing $\mathrm{P}-\mathrm{GP}$ in this organ (12). A pilot experiment showed that $4 \mathrm{~h}$ after administration, the level of radioactivity in brain was only twofold higher in $m d r 1 a(-/-)$ mice than in wild-type mice, whereas the plasma levels were identical (data not shown).

Finally, we tested the tissue distribution of radioactivity $4 \mathrm{~h}$ after the oral administration of $\left[{ }^{3} \mathrm{H}\right]$ loperamide at a dose of $1 \mathrm{mg} / \mathrm{kg}$. In this case, we observed a clearly higher level (about 2- to 3-fold) of radioactivity in plasma and most tissues of mdr1a (-/-) mice, a 4-fold increase in testis, and a marked 13.5-fold increase in the brain (Table II).

As loperamide is an opioid drug that normally does not pass the blood-brain barrier, it has hardly any opiatelike effects in the CNS of animals or man $(23,24)$. Mice demonstrate highly characteristic behavioral abnormalities when they receive an opiate, such as morphine, that does enter the CNS (24). They display compulsive circling behavior (i.e., they compulsively walk in small or large circles, sometimes fast, sometimes slow, clockwise or counterclockwise, and walking can be interrupted by short or long intervals of immobility). In addition, the animals exhibit a typical crouched appearance and the tail is characteristically erected on an arched back (Straub tail). This type of morphinelike behavior could not be induced with any dose of loperamide in wild-type Swiss mice (24).

We performed a small-scale oral toxicity assay by administering various doses $(5,10,20,40,80$, or $160 \mathrm{mg} / \mathrm{kg})$ of loperamide to male mdrla (-/-) and wild-type mice (three mice in each group). The critically toxic (lethal) dose was $\sim 80 \mathrm{mg} / \mathrm{kg}$ for wild-type mice and $\sim 10-20 \mathrm{mg} / \mathrm{kg}$ for $m d r 1 a(-/-)$ mice. A striking difference was seen in the behavior of the mice at all dosages up to $80 \mathrm{mg} / \mathrm{kg}$; whereas wild-type mice merely demonstrated passivity and malaise as evident from piloerection, the mdrla (-/-) mice demonstrated a full-blown picture of
Table II. Tissue Levels of Radioactivity in mdr1a (+/+) and $(-/-)$ Mice $4 \mathrm{H}$ after Oral Injection of $\left.{ }^{3} \mathrm{H}\right]$ Loperamide $(1 \mathrm{mg} / \mathrm{kg})$

\begin{tabular}{lccc}
\hline & & & Ratio \\
\cline { 3 - 4 } \multicolumn{1}{c}{ Tissue } & $m d r 1 a(+/+)$ & $m d r 1 a(-/-)$ & $(-/-):(+/+)$ \\
\hline Brain & $4.1 \pm 1.1$ & $55.3 \pm 1.9$ & $13.5^{*}$ \\
Muscle & $19.4 \pm 19.8$ & $59.5 \pm 22.0$ & 3.1 \\
Heart & $48.6 \pm 17.8$ & $99.0 \pm 9.5$ & $2.0^{\ddagger}$ \\
Kidney & $356 \pm 119$ & $546 \pm 85$ & 1.5 \\
Liver & $73.7 \pm 26.2$ & $227 \pm 62$ & $3.1^{\ddagger}$ \\
Gall bladder & $2,146 \pm 1,137$ & $5,660 \pm 5,179$ & 2.6 \\
Lung & $322 \pm 129$ & $534 \pm 64$ & 1.7 \\
Stomach & $605 \pm 321$ & $1,064 \pm 615$ & 1.8 \\
Small intestine & $293 \pm 61$ & $519 \pm 145$ & 1.8 \\
Colon & $81.1 \pm 22.8$ & $185 \pm 14$ & $2.3^{\S}$ \\
Testis & $10.0 \pm 3.5$ & $38.4 \pm 6.2$ & $3.8^{\S}$ \\
Spleen & $90.0 \pm 20.6$ & $173 \pm 11$ & $1.9^{\S}$ \\
Plasma & $13.3 \pm 3.4$ & $26.7 \pm 2.3$ & $2.0^{\S}$ \\
& & & \\
\hline
\end{tabular}

Results are expressed as means $\pm \mathrm{SD}(n-1)$ in nanograms per gram tissue $\left(\left[{ }^{3} \mathrm{H}\right]\right.$ loperamide equivalent $)$. Three mice were analyzed in each group. ${ }^{*} P<0.001 ;{ }^{\ddagger} P<0.05 ;{ }^{\circledR} P<0.01$.

central opiatelike effects: pronounced excitement characterized by compulsive circling movements interrupted by periods of immobility, a crouched appearance, and an erected tail on an arched back. No piloerection was seen in mdrla (-/-) mice. Even the lowest dose tested $(5 \mathrm{mg} / \mathrm{kg})$ induced crouching, Straub tail, and compulsive circling in mdrla (-/-) mice. The characteristic expression of this opiatelike behavior lasted considerably longer at higher dosages (up to $2 \mathrm{~d}$ at $10 \mathrm{mg} / \mathrm{kg}$ ). These results indicate that loperamide has pronounced opiatelike effects in the CNS of mdrla (-/-) mice.

\section{Discussion}

This study identifies additional clinically important drugs that are (or are not) transported substrates of the human MDR1 and the mouse mdr1a P-GP. It also indicates that the specific pharmacodynamic activity of several of these drugs (e.g., domperidone, or loperamide) may depend on the fact that they are good P-GP substrates, and consequently do not pass the blood-brain barrier efficiently.

Domperidone is a highly efficient and specific dopamine antagonist drug in vitro, but unlike other dopamine antagonists, such as haloperidol, it cannot be used as an antipsychotic (neuroleptic) drug because it does not readily cross the bloodbrain barrier $(25,26)$. Consequently, domperidone has mainly pharmacological activity outside of the area protected by this barrier. It is therefore used clinically as an antiemetic agent, owing to its action on peripheral dopamine receptors. As a dopamine antagonist that does not enter the CNS, it can be used to counteract the unwanted (dose-limiting) peripheral side effects of dopamine-agonistic drugs that are primarily intended to activate dopamine receptors in the CNS, such as bromocriptine and levodopa, which are used for the treatment of Parkinson's disease. Our data suggest that the lack of penetration of domperidone into the brain could be explained by its active removal from the brain by P-GP residing in the blood- 
brain barrier. In contrast, haloperidol can be successfully used as a centrally active neuroleptic agent (18), probably because it is hardly affected by P-GP-mediated back transport.

The clinical use of the antidiarrheal drug loperamide may also be critically dependent on the presence of P-GP in the blood-brain barrier. Structurally, loperamide is a typical opioid drug, like morphine and related compounds. However, in animal models and in humans, loperamide nearly exclusively demonstrates peripheral opiatelike effects on the gastrointestinal tract, leading to constipation, whereas pharmacological effects on the CNS are hardly ever observed $(18,23,24)$. Loperamide is therefore used as a relatively innocuous antidiarrheal drug. Our results from the in vitro drug transport assay, the in vivo drug distribution, and the in vivo pharmacological effects of loperamide in mdrla $(-/-)$ mice clearly indicate that P-GP in the blood-brain barrier is the main factor responsible for this selective (peripheral) pharmacological behavior of loperamide.

Although our data suggest that the tissue distribution and (by implication) pharmacokinetics of the widely used antiemetic drug ondansetron will be affected to some extent by the presence or absence of functionally active P-GP, we do not expect that this will have qualitative consequences for the clinical use of this drug. Ondansetron has some affinity for 5-hydroxytryptamine $_{1 \mathrm{~B}}$, 5-hydroxytryptamine $\mathrm{f}_{\mathrm{C}}, \alpha$-adrenergic, and opioid $\mu$ receptors, but it has at least 250 -fold higher affinity for its

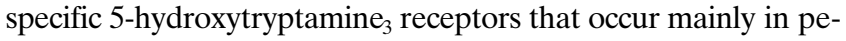
ripheral target tissues such as the vagal afferent nerves (27). This, combined with the relatively moderate transport of ondansetron by the human MDR1 P-GP, suggests that the pharmacological effects of ondansetron would not be drastically affected by the absence of active P-GP in humans. However, some of the side effects of ondansetron might be related to the degree of entry into the CNS, so blocking of P-GP in the blood-brain barrier, for instance by coadministration of an effective P-GP inhibitor such as PSC 833 (15), might exacerbate such side effects.

For the antiepileptic drug phenytoin, the situation is potentially more complex. In vitro, phenytoin is clearly a poorer substrate for both MDR1 and mdr1a P-GP than ondansetron. However, the pharmacological target of phenytoin is probably brain tissue positioned behind the blood-brain barrier, and phenytoin must therefore pass this barrier to be therapeutically active. The cause of many forms of epilepsy and the mechanism of action of the therapeutic drugs is not completely understood (18). Phenytoin is one of the primary drugs for treatment of epilepsy, but some patients display resistance to treatment (18). Tishler et al. (21) recently found that brain tissue taken from affected areas in patients with such intractable epilepsy frequently displayed increased levels of MDR1 P-GP in capillary endothelia and even in astrocytes when compared to normal brain tissue. Although these changes could be secondary to other phenomena correlating with the intractable epilepsy, it is also possible that the inordinately high levels of $\mathrm{P}-\mathrm{GP}$, in spite of the relatively inefficient transport of phenytoin, are sufficient to bring the phenytoin concentrations in brain parenchyme below the therapeutic level, and thus cause therapy resistance. This possibility was previously considered by Tishler et al. (21).

In view of the potential clinical significance of P-GP in the blood-brain barrier for many drugs, it is important that highly effective P-GP inhibitors such as PSC 833 are currently used in clinical trials and may become available in the near future. These compounds may be effective enough to substantially block P-GP in the blood-brain barrier of patients. Coadministration of PSC 833 may therefore increase the therapeutic efficacy of some drugs (e.g., phenytoin), or the unwanted CNS side effects (e.g., domperidone, loperamide, or digoxin), or it may qualitatively alter the therapeutic applications of some drugs (e.g., domperidone, loperamide and, probably, many other drugs as well).

The extent to which drugs can penetrate the blood-brain barrier is a major issue in clinical pharmacology, and there is great interest in developing simple methods to predict whether a certain compound will or will not pass this barrier efficiently. A major conundrum has been the finding that many relatively hydrophobic drugs, that were expected to easily diffuse across lipid membranes, did not readily enter the brain (28-31). Based on our findings so far, we propose that many, if not all, of these discrepancies are explained by the fact that these drugs are efficiently transported back to the blood by P-GP in the blood-brain barrier. Seelig et al. (31) proposed an elaborate combination of physicochemical properties including surface activity, critical micellar concentration, and surface area of a drug at the air-water interface, that could predict the relatively low brain penetration of at least six hydrophobic drugs. It is of interest that two of these six compounds were domperidone and loperamide, effective P-GP substrates (as we have shown here). Moreover, another of these compounds, terfenadine (an antihistaminic drug with little CNS side effects), has been shown to reverse P-GP-mediated drug resistance, suggesting that it also interacts with P-GP (32). In contrast, haloperidol was classified by Seelig et al. (31) as a drug with physicochemical properties that would allow easy brain penetration. In our study we have shown that haloperidol is a very poor P-GP substrate. We therefore speculate that the set of physicochemical properties described by these authors merely represents the properties of a good P-GP substrate drug. In that case, it may be more straightforward to simply test whether a drug is efficiently transported by P-GP to predict whether a drug will readily pass the blood-brain barrier.

The physicochemical parameters used by Seelig et al. (31) are also potentially relevant for the interaction of drugs with phospholipid membranes. We therefore listed the rate with which a range of drugs can passively diffuse through the LLCPK1 monolayer as a crude estimate of the rate of diffusion of these drugs across lipid bilayers and compared this with the molecular size of the drugs and the extent to which a drug is a good P-GP substrate in the L-mdr1a cells (Table III: data from this study, reference 14, and unpublished results). Comparison of these properties shows that there is no simple correlation between these three parameters. Relatively small drugs (phenytoin, morphine, or ondansetron) can be better substrates for P-GP than some larger drugs (flunitrazepam, clozapine, or haloperidol). Rapidly diffusing drugs with similar molecular size may be either (fairly) good substrates (ondansetron, or domperidone), or poor substrates (flunitrazepam, or haloperidol). Importantly, this comparison shows that the physicochemical parameters proposed by Seelig et al. (31) do not simply define drugs that diffuse very slowly across membranes (e.g., haloperidol and domperidone, classified in different physicochemical groups, but each with similar high diffusion rates of $16-17 \%$ per hour). This further supports our conjecture that the proposed physicochemical parameters may primarily relate to the ability of a substrate to be transported by P-GP. If this turns out to be true, this may resolve the long- 
Table III. Passive Diffusion Rates and P-Glycoprotein-mediated Transport of Selected Drugs (Listed by Molecular Weight, $M_{r}$ ) in LLC-PK1, L-MDR1, and L-mdr1a Cells

\begin{tabular}{|c|c|c|c|}
\hline Drug & $M_{\mathrm{r}}$ & Diffusion rate & $\begin{array}{l}\text { P-glycoprotein substrate } \\
\text { in vitro* }\end{array}$ \\
\hline & & percent/h & \\
\hline Phenytoin & 252 & 18 & + \\
\hline Morphine & 285 & 4 & + \\
\hline Ondansetron & 293 & 25 & $+(+)$ \\
\hline Flunitrazepam & 313 & 28 & - \\
\hline Clozapine & 327 & 17 & - \\
\hline Haloperidol & 376 & 17 & - \\
\hline Dexamethasone & 392 & 11 & ++ \\
\hline Domperidone & 426 & 16 & $++(+)$ \\
\hline Loperamide & 477 & 13 & ++ \\
\hline Daunorubicin & 528 & $4-7$ & ++ \\
\hline Etoposide & 589 & 1.5 & ++ \\
\hline Digoxin & 781 & 3 & ++ \\
\hline Vinblastine & 811 & 6 & $++(+)$ \\
\hline Paclitaxel & 854 & $6-8$ & +++ \\
\hline Ivermectin (B1a) & 874 & 4 & ++ \\
\hline Cyclosporin A & 1,203 & 5 & ++ \\
\hline
\end{tabular}

Data are from Schinkel et al. (14), this study, and Schinkel, A.H., E. Wagenaar, C.A.A.M. Mol, and L. van Deemter, unpublished. *Drugs not transported by L-MDR1 and hardly by L-mdr1a were scored - .

standing question of which properties make a compound a good substrate for the drug-transporting P-GPs.

In general, we propose that it will be highly useful to establish for clinically important or promising drugs whether they are good P-GP substrates or not, as this may greatly help in understanding or predicting the pharmacological behavior of such drugs, especially those with CNS (side-)effects.

\section{Acknowledgments}

We thank Dr. P. Borst for advice and support, and our colleagues for critical reading of the manuscript. We are indebted to A.J. Schrauwers for excellent biotechnical assistance, Dr. B.M. Bain (Glaxo, Greenford, UK) for providing radiolabeled ondansetron, and Dr. D. Cohen (Sandoz, East Hanover, NJ) for providing PSC 833. We thank Dr. P. Gros (McGill University, Montreal) for providing us with mouse $m d r$ cDNAs.

This work was supported in part by grant NKI 92-41 of the Dutch Cancer Society to P. Borst.

\section{References}

1. Juliano, R.L., and V. Ling. 1976. A surface glycoprotein modulating drug permeability in Chinese hamster ovary cell mutants. Biochim. Biophys. Acta. 455:152-162

2. Gros, P., J. Croop, and D. Housman. 1986. Mammalian multidrug resistance gene: complete cDNA sequence indicates strong homology to bacterial transport proteins. Cell. 47:371-380.

3. Chen, C., J.E. Chin, K. Ueda, D.P. Clark, I. Pastan, M.M. Gottesman, and I.B. Roninson. 1986. Internal duplication and homology with bacterial transport proteins in the $m d r 1$ (P-glycoprotein) gene from multidrug-resistant human cells. Cell. 47:381-389.

4. Endicott, J.A., and V. Ling. 1989. The biochemistry of P-glycoproteinmediated multidrug resistance. Annu. Rev. Biochem. 58:137-171.

5. Gottesman, M.M., and I. Pastan. 1993. Biochemistry of multidrug resistance mediated by the multidrug transporter. Annu. Rev. Biochem. 62:385-427.
6. Hsu, S.I., L. Lothstein, and S.B. Horwitz. 1989. Differential overexpression of three $m d r$ gene family members in multidrug-resistant $\mathrm{J} 774.2$ mouse cells. J. Biol. Chem. 264:12053-12062.

7. Devault, A., and P. Gros. 1990. Two members of the mouse $m d r$ gene family confer multidrug resistance with overlapping but distinct drug specificities. Mol. Cell. Biol. 10:1652-1663.

8. Thiebaut, F., T. Tsuruo, H. Hamada, M.M. Gottesman, I. Pastan, and M.C. Willingham. 1987. Cellular localization of the multidrug resistance gene product in normal human tissues. Proc. Natl. Acad. Sci. USA. 84:7735-7738.

9. Croop, J.M., M. Raymond, D. Haber, A. Devault, R.J. Arceci, P. Gros, and D.E. Housman. 1989. The three mouse multidrug resistance $(m d r)$ genes are expressed in a tissue-specific manner in normal mouse tissue. Mol. Cell. Biol. 9:1346-1350.

10. Arceci, R.J., J.M. Croop, S.B. Horwitz, and D. Housman. 1988. The gene encoding multidrug resistance is induced and expressed at high levels during pregnancy in the secretory epithelium of the uterus. Proc. Natl. Acad. Sci. USA. 85:4350-4354.

11. Sugawara, I., I. Kataoka, Y. Morishita, H. Hamada, T. Tsuruo, S. Itoyama, and S. Mori. 1988. Tissue distribution of P-glycoprotein encoded by a multidrug-resistant gene as revealed by a monoclonal antibody, MRK16. Cancer Res. 48:1926-1929.

12. Cordon-Cardo, C., J.P. O'Brien, D. Casals, L. Rittman-Grauer, J.L. Biedler, M.R. Melamed, and J.R. Bertino. 1989. Multidrug-resistance gene (P-glycoprotein) is expressed by endothelial cells at blood-brain barrier sites. Proc. Natl. Acad. Sci. USA. 86:695-698.

13. Schinkel, A.H., J.J.M. Smit, O. van Tellingen, J.H. Beijnen, E. Wagenaar, L. van Deemter, C.A.A.M. Mol, M.A. van der Valk, E.C. RobanusMaandag, H.P.J. te Riele, et al. 1994. Disruption of the mouse mdr1a P-glycoprotein gene leads to a deficiency in the blood-brain barrier and to increased sensitivity to drugs. Cell. 77:491-502.

14. Schinkel, A.H., E. Wagenaar, L. van Deemter, C.A.A.M. Mol, and P. Borst. 1995. Absence of the mdr1a P-glycoprotein in mice affects tissue distribution and pharmacokinetics of dexamethasone, digoxin, and cyclosporin A. $J$. Clin. Invest. 96:1698-1705.

15. Boesch, D., C. Gavériaux, B. Jachez, A. Pourtier-Manzanedo, P. Bollinger, and F. Loor. 1991. In vivo circumvention of P-glycoprotein-mediated multidrug resistance of tumor cells with SDZ PSC 833. Cancer Res. 51:4226-4233.

16. Dalton, W.S., T.M. Grogan, P.S. Meltzer, R.J. Scheper, B.G.M. Durie, C.W. Taylor, T.P. Miller, and S.E. Salmon. 1989. Drug-resistance in multiple myeloma and non-Hodgkin's lymphoma: detection of P-glycoprotein and potential circumvention by addition of verapamil to chemotherapy. J. Clin. Oncol. 7:415-424.

17. Sikic, B.I. 1993. Modulation of multidrug resistance: at the threshold. J. Clin. Oncol. 11:1629-1635.

18. Gilman, A.G., T.W. Rall, A.S. Nies, and P. Taylor. 1991. The Pharmacological Basis of Therapeutics. McGraw-Hill Book Co., Singapore. 1811 pp.

19. Horio, M., K.-v. Chin, S.J. Currier, S. Goldenberg, C. Williams, I. Pastan, M.M. Gottesman, and J. Handler. 1989. Transepithelial transport of drugs by the multidrug transporter in cultured Madin-Darby canine kidney cell epithelia. J. Biol. Chem. 264:14880-14884.

20. Ueda, K., N. Okamura, M. Hirai, Y. Tanigawara, T. Saeki, N. Kioka, T. Komano, and R. Hori. 1992. Human P-glycoprotein transports cortisol, aldosterone, and dexamethasone, but not progesterone. J. Biol. Chem. 267:2424824252.

21. Tishler, D.M., K.I. Weinberg, D.R. Hinton, N. Barbaro, G.M. Annett, and C. Raffel. 1995. MDR1 gene expression in brain of patients with medically intractable epilepsy. Epilepsia. 36:1-6.

22. Heykants, J., A. Knaeps, W. Meuldermans, and M. Michiels. 1981. On the pharmacokinetics of domperidone in animals and man. I. Plasma levels of domperidone in rats and dogs. Age related absorption and passage through the blood brain barrier in rats. Eur. J. Drug Metab. Pharmacokinet. 6:27-36.

23. Niemegeers, C.J.E., F.M. Lenaerts, and P.A.J. Janssen. 1974. Loperamide ( $\mathrm{R} 18$ 553), a novel type of antidiarrheal agent. Part 1: in vivo oral pharmacology and acute toxicity. Comparison with morphine, codeine, diphenoxylate and difenoxine. Arzneim.-Forsch. (Drug Research). 24:1633-1636.

24. Niemegeers, C.J.E., F.M. Lenaerts, and P.A.J. Janssen. 1974. Loperamide ( $\mathrm{R} 18$ 553), a novel type of antidiarrheal agent. II. In vivo parenteral pharmacology and acute toxicity in mice. Comparison with morphine, codeine, and diphenoxylate. Arzneim.-Forsch. (Drug Research). 24:1636-1641.

25. Laduron, P.M., and J.E. Leysen. 1979. Domperidone, a specific in vitro dopamine antagonist, devoid of in vivo central dopaminergic activity. Biochem. Pharmacol. 28:2161-2165.

26. Brogden, R.N., A.A. Carmine, R.C. Heel, T.M. Speight, and G.S. Avery. 1982. Domperidone. A review of its pharmacological activity, pharmacokinetics and therapeutic efficacy in the symptomatic treatment of chronic dyspepsia and as an antiemetic. Drugs. 24:360-400.

27. Perez, E.A. 1995. Review of the preclinical pharmacology and comparative efficacy of 5-hydroxytryptamine-3 receptor antagonists for chemotherapyinduced emesis. J. Clin. Oncol. 13:1036-1043.

28. Levin, V.A. 1980. Relationship of octanol/water partition coefficient and molecular weight to rat brain capillary permeability. J. Med. Chem. 23:682-684.

29. Bradbury, W.B. 1985. The blood-brain barrier: transport across the ce- 
rebral endothelium. Circ. Res. 57:213-222.

30. Cefalu, W.T., and W.M. Pardridge. 1985. Restrictive transport of a lipidsoluble peptide (cyclosporin) through the blood-brain barrier. J. Neurochem. 45:1954-1956

31. Seelig, A., R. Gottschlich, and R.M. Devant. 1994. A method to deter- mine the ability of drugs to diffuse through the blood-brain barrier. Proc. Natl. Acad. Sci. USA. 91:68-72.

32. Hait, W.N., J.F. Gesmonde, J.R. Murren, J.M. Yang, H.X. Chen, and M. Reiss. 1993. Terfenadine (Seldane ${ }^{\circledR}$ ): a new drug for restoring sensitivity to multidrug resistant cancer cells. Biochem. Pharmacol. 45:401-406. 